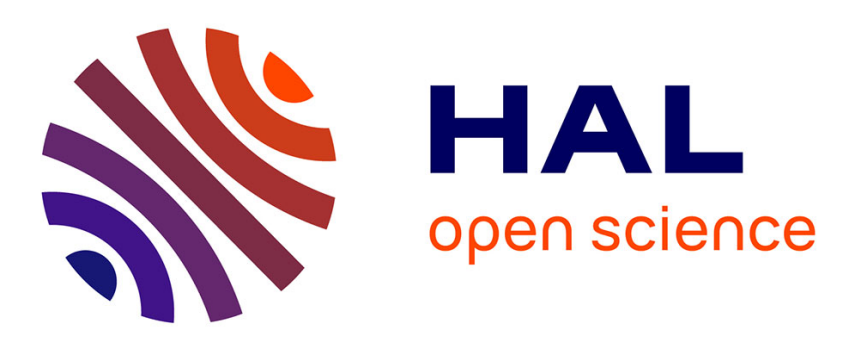

\title{
Inheritance of the number of red spots on the skin of the brown trout
}

\author{
J.M. Blanc, Bernard Chevassus-Au-Louis, Francine Krieg
}

\section{To cite this version:}

J.M. Blanc, Bernard Chevassus-Au-Louis, Francine Krieg. Inheritance of the number of red spots on the skin of the brown trout. Aquatic Living Resources, 1994, 7, pp.133-136. hal-02708169

\section{HAL Id: hal-02708169 \\ https://hal.inrae.fr/hal-02708169}

Submitted on 1 Jun 2020

HAL is a multi-disciplinary open access archive for the deposit and dissemination of scientific research documents, whether they are published or not. The documents may come from teaching and research institutions in France or abroad, or from public or private research centers.
L'archive ouverte pluridisciplinaire HAL, est destinée au dépôt et à la diffusion de documents scientifiques de niveau recherche, publiés ou non, émanant des établissements d'enseignement et de recherche français ou étrangers, des laboratoires publics ou privés. 


\title{
Inheritance of the number of red spots on the skin of the brown trout
}

\author{
Jean-Marie Blanc ${ }^{(1)}$, Bernard Chevassus ${ }^{(2)}$ and Francine Krieg \\ (1) Stalion d'Hydrohiologie, INRA, 64310 Saint-Pëe-sur-Nivelle, France. \\ (2) Laboratoire de Génétique des Poissons, INRA, 78350 Jouy-en-Josas, France.
}

Received September 29, 1993 ; accepted December 13, 1993.

Blanc J. M., B. Chevassus, F. Krieg. Aquat. Living Resour., 1994, 7, 133-136.

Transmission héréditaire du nombre de points rouges de la robe chez la truite commune.

\section{INTRODUCTION}

Aquacultural research on brown trout, Salmo trutta, has developed during the past ten years, within the context of French mariculture (Quillet et al., 1992). Traditionally, brown trout breeding was limited to the enhancement of natural stocks for recreational or professional fisheries, because the rainbow trout, Oncorhynchus mykiss (Walbaum) grows better in intensive freshwater culture. With the development of marine fish farming, interest in the brown trout grew because it tolerates high temperature and salinity better than the rainbow trout and exhibits growth performance comparable to that of the Atlantic salmon, Salmo salar (Krieg et al., 1992).

However, according to Quillet et al. (1986, 1992), the colour of sea-grown brown trout differs from that of Atlantic salmon: it is less silvery, sometimes yellowish, with a variable occurrence of black and red spots. This may result from the use of nonanadromous strains, chosen on the sole basis of growth performance. It is also dependent upon the environment, especially the size of the cage (Quillet et al., 1992).

The presence of spotting on the fish does not fulfil the consumer's image of a marine species and is possibly reducing market acceptance, unless the fish is filleted. It has been shown that black spotting is an inherited trait with a heritability of 0.4 and would be susceptible to negative selection (Blanc et al., 1982). This paper looks at the possibility of estimating the heritability of red spots in brown trout and adds to earlier work presented at Fludir (Iceland) in August 1991 (Chevassus et al., 1992).

\section{MATERIAL AND METHODS}

Adult breeders from the broodstock of the INRA fish farm of Gournay-sur-Aronde (Oise, France) were chosen according to the number of red spots on the skin. Spots were counted on both sides of each fish. Small and/or faint spots were counted as $1 / 2$ each. Two divergent pools of females were selected, i.e. 6 dams exhibiting 0 to 21 spots and 7 dams exhibiting 52 to 145 spots, and spawns were mixed in each pool. Two experimental designs were set up, as presented in table 1: (A) a factorial cross of 8 individual sires, ranging from 11 to 89 spots, with the two pools of dams; (B) a divergent selection where the same pools of dams were respectively crossed with two pools of males; these were on one hand the 2 "lowest" sires of the factorial design (11 and 25 spots) and on the other hand the 3 "highest" ones ( 80 to 89 spots) plus an outsider (102 spots); the milt from each male was used separately as in the A-design, and pooling was carried out after fertilization had taken place.

The two selected lines from the B-design were maintained in the fish farm of Goumay-sur-Aronde, where they were raised (separate tanks, no replicate), until the age of 23 months $(30 \mathrm{~cm}$ - average total length). Then 40 fish were randomly sampled from each line, and sex, total length, and numbers of red spots anterior and posterior to the dorsal fin, were recorded. Red spots were counted on the left side 
only (the total number on both sides was therefore evaluated as twice that count), small and/or faint spots being counted as $1 / 2$ each.

The 16 families from the A-design were incubated at the INRA fish genetics laboratory of Jouy-enJosas, then transferred to the INRA fish farm of Lées-Athas (Pyrénées-Atlantiques, France) where they were raised (separate tanks, no replicate) up to the age of 32 months $(21 \mathrm{~cm} \mathrm{-} \mathrm{average} \mathrm{total} \mathrm{length).}$ Growth was much slower than in Gournay-sur-Aronde, probably due to the low temperature $\left(8^{\circ} \mathrm{C}\right)$ of the mountain spring water at Lées-Athas. From the age of 16 month-old, the fish were given a $25 \mathrm{mg} / \mathrm{kg}$ canthaxanthin-supplemented diet so as to brighten their spotting. At the age of 32 months, 20 fish were randomly sampled from each family, and their total length, and numbers of red spots anterior and posterior to the dorsal fin, were recorded. Red spots were counted on each side of the body, small and/or faint spots being counted as $1 / 2$ each.

Data were processed using standard methods of analysis of variance, regression and correlation (Snedecor and Cochran, 1967). The heritability of the number of red spots was estimated according to Falconer (1960), from the regressions of offspring on sires and on dams (factorial design) and from the ratio of response to selection differential (divergent selection design).

\section{RESULTS}

The numbers of red spots in the various groups of offspring obtained from each experimental design are presented in table 1. The overall mean of the factorial cross progeny (57.3) was significantly greater $(p<0.001)$ than that of the divergent selection progeny
(45.8), although both designs had similar mid-parent average values (48.0 and 49.0, respectively).

Comparison among sexes in the divergent selection design (table 1, B) showed a significant sexual effect $(p<0.001)$ in the low line, where males displayed more than twice as many spots as females. In contrast, sexes in the high line did not differ significantly.

From the analysis of variance on body length ( $\mathrm{L}$ mean square, table 2) there was no evidence of any paternal or maternal effect in the factorial design. The other significant mean squares were at least partly attributable to common environmental variation. Among individuals within tanks, the number of red spots was found to be correlated to body 'length. However, this was significant in the factorial design only, and the weighted average of estimates from both designs $(r=0.21)$ was not large enough to justify a correction of the number of spots through regression on body length.

It was evident from the analysis of variance of the number of red spots in the factorial design ( $\mathrm{N}$ mean square, table 2) that a major and significant part of the variation of paternal origin was attributable to the regression of that variable on the number of spots of the corresponding sires (regression slope: 0.25 ). A significant variation of maternal origin was also observed, which showed a regression on the mean number of spots of the corresponding pools of dams (slope: 0.37). In line with these results, the response to the divergent selection was also significant, though it was not free from bias due to the common environmental variation.

The factorial design therefore provided two independent estimates of heritability (table 3), obtained by doubling the regression slopes on sire and on dam performances. These two estimates did

Table 1. - Number of red spots (both sides) in brown trout breeders and their progenies.

A. Factorial cross of 8 individual sires with 2 pools of dams: mean \pm its standard-error from 20 offspring per cell.

\begin{tabular}{|c|c|c|c|c|c|c|c|c|c|}
\hline \multicolumn{2}{|c|}{ Spots on dams } & \multicolumn{8}{|c|}{ Spots on individual sires } \\
\hline Range & Mean & 11 & 25 & 33 & 41 & 48 & 80 & 84 & 89 \\
\hline $0-21$ & 8.8 & $42.2 \pm 5.5$ & $28.6 \pm 3.2$ & $36.1 \pm 3.4$ & $37.6 \pm 3.6$ & $38.8 \pm 3.9$ & $65.8 \pm 4.9$ & $58.0 \pm 4.5$ & $43.7 \pm 4.2$ \\
\hline $52-145$ & 80.6 & $66.5 \pm 5.6$ & $62.0 \pm 5.4$ & $66.8 \pm 3.4$ & $71.1 \pm 4.7$ & $65.2 \pm 3.7$ & $68.5 \pm 5.3$ & $86.0 \pm 5.4$ & $79.1 \pm 6.6$ \\
\hline
\end{tabular}

B. Divergent selection: progeny mean \pm its standard-error $(n=$ number of fish in each sex; 40 offspring per selected line).

\begin{tabular}{|c|c|c|c|c|c|c|}
\hline \multirow{2}{*}{ Selected line } & \multicolumn{2}{|c|}{ Spots on dams } & \multicolumn{2}{|c|}{ Spots on sires } & \multicolumn{2}{|c|}{ Spots on progenies } \\
\hline & Range & Mean & Range & Mean & $\operatorname{Sex}(n)$ & Mean \pm s.e. \\
\hline Low & $0-21$ & 8.8 & $11-25$ & 18.0 & $\begin{array}{l}m(16) \\
f(24)\end{array}$ & $\begin{array}{l}29.6 \pm 3.3 \\
13.6 \pm 2.2\end{array}$ \\
\hline High & $52-145$ & 80.6 & $80-102$ & 88.7 & $\begin{array}{l}m(18) \\
f(22)\end{array}$ & $\begin{array}{l}67.7 \pm 5.2 \\
74.9 \pm 4.7\end{array}$ \\
\hline
\end{tabular}


Table 2. - Analysis of variance of the number $\mathrm{N}$ of red spots among offspring, and covariance with their body length $\mathrm{L}(\mathrm{mm})$.

\begin{tabular}{lcccc}
\hline $\begin{array}{l}\text { Source } \\
\text { of variation }\end{array}$ & d.f. & $\begin{array}{c}\text { N mean } \\
\text { square }\end{array}$ & $\begin{array}{c}\text { L mean } \\
\text { square }\end{array}$ & $\begin{array}{l}\text { N, L mean product } \\
\text { (correlation) }\end{array}$ \\
\hline
\end{tabular}

\begin{tabular}{lrcccc}
$\begin{array}{l}\text { A. Factorial cross } \\
\text { Regression on }\end{array}$ & 1 & $14983^{* *}$ & & & \\
sires & 6 & $1196 \mathrm{~ns}$ & & & \\
Paternal deviation & 7 & $3166 \mathrm{~ns}$ & $1704 \mathrm{~ns}$ & 1110 & $(0.48) \mathrm{ns}$ \\
Total paternal & 1 & $57459^{* * *}$ & $3830 \mathrm{~ns}$ & -14834 & $(-1.00) \mathrm{ns}$ \\
Maternal & 7 & $1100^{*}$ & $2701^{* * *}$ & -1047 & $(-0.61) \mathrm{ns}$ \\
Non-additive $\left(^{\mathrm{a}}\right)$ & 304 & 438 & 254 & 88 & $(0.26)^{* * *}$ \\
Individual & & & & & \\
\hline
\end{tabular}

B. Divergent selection

\begin{tabular}{lrcccc}
$\begin{array}{l}\text { Selected line }\left({ }^{\mathrm{a}}\right) \\
\text { Individual }\end{array}$ & 1 & $53354 * * *$ & $11568 * * *$ & -24843 & $(-1.00) \mathrm{ns}$ \\
& 78 & 343 & 285 & 14 & $(0.05) \mathrm{ns}$ \\
\hline
\end{tabular}

Levels of significance: $* 0.05 ; * * 0.01 ; * * * 0.001$; ns not significant. (a) including common environment ("tank-effect").

not differ significantly from each other, and their weighted mean was 0.67 (with standard error 0.08 ). A third estimate, which fell close to that mean, was obtained as the ratio of the selection response to the selection differential (i.e. the slope of the regression on the mean numbers of spots of the parents of the respective selected lines).

The analysis of the lateral (left $v s$. right) variation of spots within the 320 offspring from the factorial design did not show any significant lack of symmetry. Moreover, the difference between the left (L) and right (R) numbers of spots was much less than could be expected in the hypothesis of a random distribution of the spots: the quantity $(\mathrm{L}-\mathrm{R})^{2} /(\mathrm{L}+\mathrm{R})$, which was supposed to be a chi-square with one degree of freedom for each fish (Snedecor and Cochran, 1967), actually averaged 0.18 , which was significantly much less than the chi-square expectation (theoretical value $=1.00$ ).

The comparison of the numbers of spots anterior (A) and posterior (P) to the dorsal fin showed that these two quantities were not related to each other by a simple proportionality. Rather, there was a linear relationship of the form: $P-A=D$. The difference $D$ was independent from the total spotting of the fish, from its paternal or maternal origin and from the experimental design considered. Among the 400 offspring studied, D was distributed with mean 6.8 and standard deviation 7.0 (left and right sides added).

Table 3. - Estimates of heritability for the number of red spots.

Method of

estimation

\begin{tabular}{llll}
\hline Factorial cross: & $\begin{array}{l}\text { Regression on sires } \\
\text { Regression on pools } \\
\text { of dams }\end{array}$ & 0.50 & 0.14 \\
$\begin{array}{l}\text { Response to } \\
\text { divergent selection }\end{array}$ & 0.73 & 0.10 \\
\hline
\end{tabular}

\section{DISCUSSION AND CONCLUSION}

The genetic inheritance of the number of red spots on the skin of the brown trout was shown, for the first time to our knowledge, by the use of two experimental designs which provided concordant results with one exception: the overall spotting mean of the progeny was higher in the factorial cross than in the divergent selection. This discrepancy may be due to the differences in environmental conditions, or to an uncontrolled divergence of spotting evaluation between the respective teams at the two locations. But, more probably, it results from the canthaxanthinsupplemented diet used at Lées-Athas, which allowed a more distinct perception of the spots.

The within-fish variation was found to be of negligible importance, the difference between the numbers of spots posterior and anterior to the dorsal fin being low and about constant. This result may be compared to the relatively weak variation observed in the antero-posterior and dorso-ventral location of black spots in brown trout (Blanc et al., 1982). However, no general conclusions can be drawn since Qadri (1959) could clearly discriminate the two cutthroat trout subspecies Oncorhynchus clarki clarki and $O$. clarki lewisi using the antero-posterior location of the black spots.

Also, the present study shows that the left (L) and right $(R)$ numbers of red spots are much closer to each other than allowed by the hypothesis of a random distribution of the spots. The same conclusion can be drawn from the results of Blanc et al. (1982): while the total $(L+R)$ number of black spots averaged 107.5 , the lateral error mean square (i.e. the mean of $(L-R)^{2} / 4$ ) was 4.3 , so it may be inferred that the mean of $(L-R)^{2} /(L+R)$ was about 0.16 , which is close to the value found in the present study, and much less than the theoretical expectation $(=1.00)$.

The between-fish variation could be partly related to the fish's state of development - body length and sex. Unfortunately, the fish were not tagged with individual identification marks, so it was not possible to check for the evolution of spotting with time. Body length was found to have only a limited influence on the number of red spots (correlation 0.21 ), while it was previously reported to affect noticeably the number of black spots in rainbow trout (Islam et al., 1973) as well as in brown trout (Blanc et al., 1982). Sexual maturation did not occur in 2-year-old fish at Lées-Athas, and a sexual difference (more spots in males) could be evidenced only in the low line of the divergent selection design at Gournay-sur-Aronde.

The most important result obtained in this study is the evidence of a strong inheritance of the number of red spots. The different heritability estimates (table 3 ), when averaged, provide an approximate evaluation $\mathrm{h}^{2}=0.7 \pm 0.1$, which is higher than the values obtained by Blanc et al. (1982) for the number of black 
spots. This value is high enough to allow the use of mass selection for the improvement of that trait. The selection could be operated in two opposite ways, depending on the type of product wanted:

- trout strains for saltwater farming of large individuals could be selected for a decrease of red spotting, in as much as this characteristic is undesirable for the consumer (Quillet et al., 1986, 1992);

- also, in a programme aiming at the improvement of trout for recreational fisheries, the selection of highly spotted strains would certainly contribute to the angler's satisfaction.

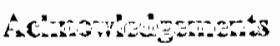

We wish to thank Huguette Poisson and the fish-culture teams of Lées-Athas and Gournay-sur-Aronde for their technical assistance.

\section{S.TETIICES}

Blanc J. M., H. Poisson, R. Vibert, 1982. Variabilité génétique de la ponctuation noire sur la truitelle Fario (Salmo trutta L.). Ann. Génét. Sél. anim., 14, 225-236.

Chevassus B., F. Írieg, R. Guyomard, J. M. Blanc, E. Quillet, 1992. The genetics of the brown trout: twenty years of French research. Buvisindi (Icel. Agr. Sci.), 6, 109-124.

Falconer D. S., 1960. Introduction to quantitative genetics. Oliver and Boyd eds., Edinburgh, 365 p.

Islam M. A., Y. Nose, F. Yasuda, 1973. Number and distribution pattern of the black spots on body surface of rainbow trout. Bull. Jpn. Soc. Sci. Fish., 39, 727-739.
Írieg F., E. Quillet, B. Chevassus, 1992. Brown trout, Salmo trutta $\mathrm{L}$.: a new species for intensive marine aquaculture. Aquacult. Fish. Manage, 23, 557-566.

Qudri S. U., 1959. Some morphological differences between the subspecies of cutthroat trout, Salmo clarkii clarkii and Salmo clarkii lewisi in British Columbia. J. Fish. Res. Board Can., 15, S03-922.

Quillet E., B. Chevassus, F. Krieg, G. Burger, 1986. Données actuelles sur l'élevage en mer de la truite commune (Salmo trutta). Piscic. Fr., OJ, 48-56.

Quillet E., A. Fauré, B. Chevassus, F. Írieg, Y. Harache, J. Arzel, R. Métailler, G. Boeuf, 1992. The potential of brown trout (Salmo trutta L.) for mariculture in temperate waters. Buvisindi (Icel. Agr. Sci.), 6, 63-76.

Snedecor G. W., W. G. Cochran, 1967. Statistical methods. The Iowa State Univ. Press, Ames, 653 p. 